\title{
Influence of various sources of nitrogen on the growth of Scots pine seedlings and the IAA content in needles
}

\author{
BARBARA KIELISZEWSKA-ROKICKA, MARIA RUDAWSKA \\ Institute of Dendrology, Polish Academy of Sciences, \\ Parkowa 5, 62-035 Kórnik, Poland \\ (Received: February 3, 1989. Revision accepted: July 5, 1989)
}

\begin{abstract}
One year old pine seedlings transferred from the nursery and potted in a greenhouse were watered with nitrogen solutions of different form and concentration (urea $0.36 \mathrm{mM}$ and $0.90 \mathrm{mM}$, ammonium tartrate $0.36 \mathrm{mM}$ and $1.79 \mathrm{mM}$, calcium nitrate $0.36 \mathrm{mM}, 1.79 \mathrm{mM}$ and $3.58 \mathrm{mM}$ ). After 10 months the growth and IAA content in needles were compared. Nitrogen fertilization affected shoot growth considerably, but its effects on root growth were less pronounced. The highest shoot weight was obtained after application of ammonium tartrate in $1.79 \mathrm{mM}$ concentration. The lowest concentration of urea $(0.36 \mathrm{mM})$ caused the same effect, as did the most concentrated calcium nitrate solution $(3.58 \mathrm{mM})$. Auxine content increased in the needles after nitrogen fertilization as compared with control. The highest accumulation of IAA was found in seedlings treated with low concentrations of urea.
\end{abstract}

Key words: ammonium, nitrate, urea, Pinus sylvestris

\section{INTRODUCTION}

Various environmental parameters (light, temperature, moisture, soil nitrogen content) have strong effects on all phases of plant growth and development, and it is not surprising that these parameters influence the content of endogenous hormones.

The response of coniferous trees to the application of nitrogen fertilizers is a major area of research in forest ecology, physiology and silviculture, however, hormonal response of conifers to nitrogen nutrition has scarcely been investigated (Michniewicz et al. 1976, Rudawska 1987). Therefore these studies were undertaken. 
We consider only the auxin indole-3-acetic acid (IAA), since this compound in herbaceous plants is known to be influenced by nitrogen nutrition (ref. Michniewicz et al. 1976) and because IAA is a major indole substance occurring in Scots pine tissues (S a ndberg 1984, S a ndberg et al. 1981, 1987, Sandberg and Ericsson 1987).

Our study was designed to determine the effects of varying fertility sources and levels on the IAA pool in the shoots of Scots pine seedlings.

\section{MATERIALS AND METHODS}

PLANT MATERIAL

One-year-old Scots pine seedlings from a nursery were transferred into the greenhouse, potted in sand and fertilized twice a week with nutrient solution during 10 months. The nitrogen sources in nutrient solutions were urea, ammonium tartrate or calcium nitrate in various concentrations (Table 1). Concentrations of nitrogen sources were chosen according to the preliminary studies (Rudawska, unpublished data) which revealed that levels of nutrients higher than $1 \mathrm{mM}$ in the case of urea and $2 \mathrm{mM}$ in the case of ammonium tartrate caused a growth inhibition of tested seedlings.

\section{Table 1}

Effect of various nitrogen sources and concentrations on growth of Scots pine seedlings ${ }^{1}$

\begin{tabular}{|l|c|l|l|l|}
\hline \multirow{2}{*}{$\begin{array}{c}\text { Nitrogen } \\
\text { compound }\end{array}$} & \multirow{2}{*}{$\begin{array}{c}\text { Concentration } \\
(\mathrm{mM})\end{array}$} & \multicolumn{3}{|c|}{ Fresh weight } \\
\cline { 3 - 5 } & & shoot $(\mathrm{g})$ & root $(\mathrm{g})$ & shoot/root \\
\hline Control & - & $18.8 \mathrm{a}$ & $17.1 \mathrm{~b}$ & $1.1 \mathrm{a}$ \\
Urea & 0.36 & $24.5 \mathrm{ab}$ & $14.7 \mathrm{a}$ & $1.7 \mathrm{~b}$ \\
& 0.90 & $32.3 \mathrm{~b}$ & $17.4 \mathrm{~b}$ & $1.9 \mathrm{~b}$ \\
Ammonium tartrate & 0.36 & $30.4 \mathrm{~b}$ & $19.3 \mathrm{bc}$ & $1.6 \mathrm{~b}$ \\
& 1.79 & $45.8 \mathrm{~d}$ & $19.9 \mathrm{c}$ & $2.3 \mathrm{bc}$ \\
Calcium nitrate & 0.36 & $28.8 \mathrm{~b}$ & $14.1 \mathrm{a}$ & $2.0 \mathrm{bc}$ \\
& 1.79 & $27.0 \mathrm{~b}$ & $17.4 \mathrm{~b}$ & $1.6 \mathrm{~b}$ \\
& 3.58 & $35.4 \mathrm{bc}$ & $17.1 \mathrm{~b}$ & $2.1 \mathrm{bc}$ \\
\hline
\end{tabular}

${ }^{1}$ Values in each row followed by the same letter do not differ significantly $(p=0.01)$.

Current year needles from treated plants ( $10 \mathrm{~g}$ for one sample) were frozen in liquid nitrogen, homogenized in $80 \%$ methanol, extracted three times with $80 \%$ methanol in darkness at $4^{\circ} \mathrm{C}$. The extracts were fractionated using the 
method adapted from Michniewicz et al. (1976) modified slightly. Extracts were reduced to dryness in vacuo. Residues were dissolved in distilled water, adjusted to $\mathrm{pH} 3.0$ and extracted with diethyl ether. Ether phases were extracted with $3 \%$ sodium bicarbonate. The bicarbonate fractions were adjusted to $\mathrm{pH} 3.0$ and extracted with diethyl ether. Ether fractions were reduced to dryness in vacuo. Dried residues were dissolved in $2 \mathrm{ml}$ of anhydrous methanol (IAA fraction). Preparative thin-layer-chromatography (TLC) was carried out on silica gel 60 using isopropanol-ethyl acetate-ammonia $(45: 35: 20 \mathrm{v} / \mathrm{v})$ as a solvent. Successive zones, or the zone corresponding to IAA only, were scraped off the plates and eluted with methanol. Methanol was evaporated in vacuo to dryness, the residues dissolved in phosphate buffer $0.01 \mathrm{M}$, pH 4.7 and bioassayed using Avena section straight test (Larsen 1955).

\section{RESULTS AND DISCUSSION}

The results presented in Table 1 showed that various nitrogen forms and concentrations had only a slight effect on the fresh weight of roots but significantly increased the fresh weight of shoots. The treatments which resulted in the highest increase of the shoot weight were ammonium as source of nitrogen at $1.79 \mathrm{mM}$ concentration and nitrate solution at $3.58 \mathrm{mM}$ concentration. The shoot/root ratio was high at $1.79 \mathrm{mM}$ ammonium as source of nitrogen and much lower on the same concentration of nitrate. Low concentration of urea nitrogen produced similar growth responses like the highest concentration of nitrate. Nitrogen nutrition significantly increased the amount of auxin in the needles of treated plants (Fig. 1). An increased level of IAA as a results of nitrogen feeding depended both on the source and on the level of nutrient used and in the case of ammonium tartrate and calcium nitrate treatments it was correlated with stimulation of shoot growth. However, the highest level of IAA was revealed in plants grown on the lower concentration of urea $(0.36 \mathrm{mM})$. These results are partly in accordance with the data of Michniewicz et al. (1976) and Rudawska (1987) who found an increased amount of IAA in ammonium fertilized plants (other sources of nitrogen and their effects on IAA level were not tested).

A representative chromatogram of the ether extract obtained from needles of tested plants is shown in Fig. 2. Chromatography revealed four growth promoting substances, one of which corresponds in Rf with IAA. The nature of the other substances was not tested, however, several indole constituents were identified in Scots pine tissues by Sandberg et al. (1981). Using gas chromatography-mass spectrometry and high-performance liquid chromatography he demonstrated the presence of indole-3-ethanol (IEt) in needles of Pinus sylvestris and showed the possible role of IEt in the metabolism of indoles in the tissue which has previously been shown to contain IAA, indole- 
CONTROL

Q UREA

Q AMMONIUM TARTRATE

IIII CALCIUM NITRATE

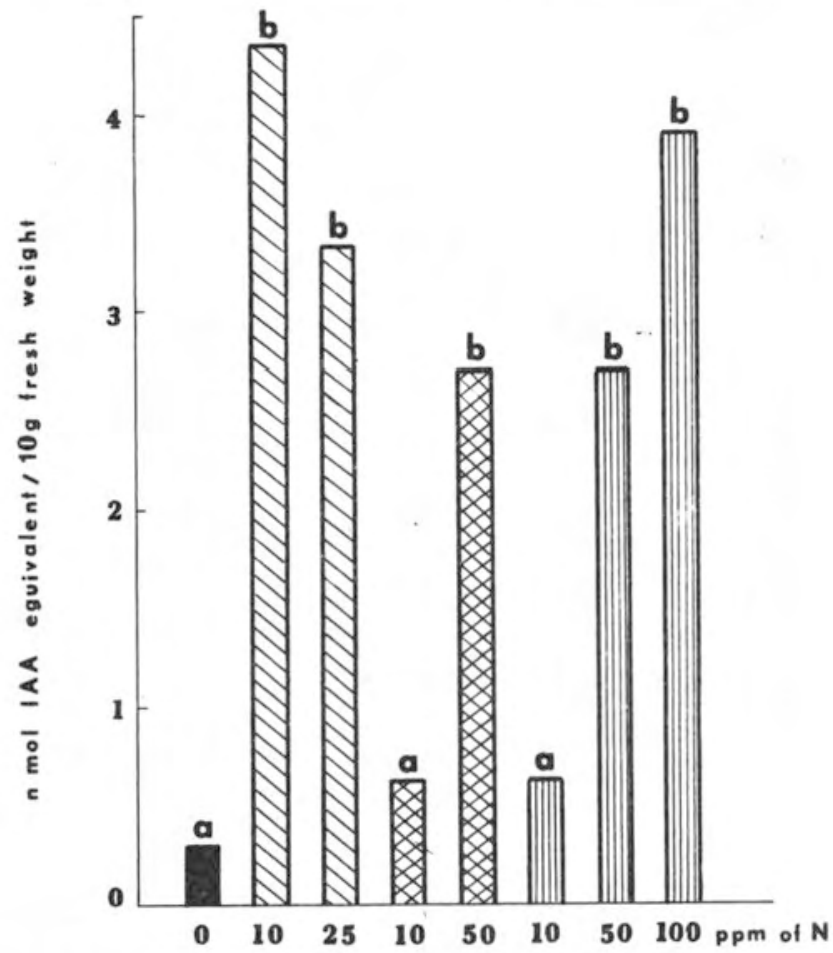

Fig. 1. The content of endogenous auxin in the needles of Scots pine seedlings treated with various nitrogen forms and levels (TLC; - Rf 0.5). Bars sharing the same letter do not differ significantly

-3-carboxylic acid and the conjugate, indole-3-aspartic acid (S a ndberg et al. 1981, Sandberg 1984, Andersson and Sandberg 1982). The results presented here showed that a very similar physiological effect (increased level of IAA) can be achieved by using various sources and levels of nitrogen. Such a response may be a result of the differentiated tolerance of pine seedlings to various nitrogen sources. In our experiment by using the method with systematically renewed nutrient solutions and watering the pot to prevent accumulation of the ions, it became possible to minimize the variation of $\mathrm{pH}$ in the root medium and to keep a physiological, constant concentration of various nutritive elements. Under such conditions the hydrolysis of urea to ammonium and carbon dioxide as well as nitrification of ammonium to nitrate were significantly limited. Thus the tested parameters of pine metabolism really reflected the influence of various sources of $\mathrm{N}\left(\mathrm{NH}_{4}^{+}, \mathrm{NO}_{3}^{-}\right.$, urea). 


\section{CALCIUM NITRATE $100 \mathrm{ppm}$ of $\mathrm{N}$}

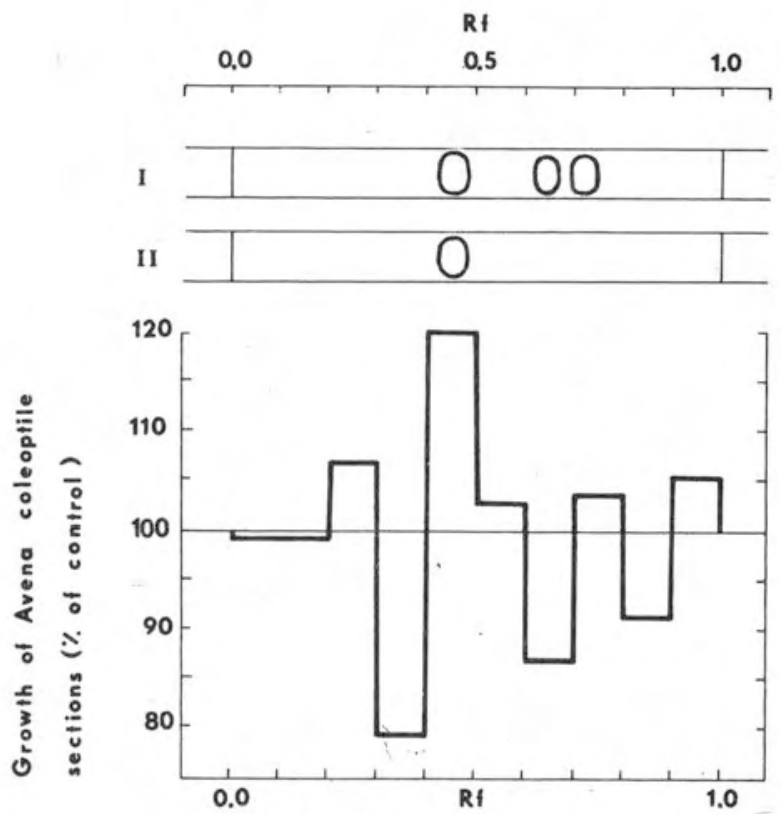

Fig. 2. Representative chromatogram of methanol extract obtained from Scots pine needles, assayed by Avena straight growth test. I - Color reaction of chromatogram by Salkowski reagent modified by Pilet (1957). II - Color reaction of IAA control

In general, the tolerance of plants to an ample supply of $\mathrm{NH}_{4}^{+}$is low, whereas the tolerance for $\mathrm{NO}_{3}^{-}$is high (Hayness 1986). Plants can tolerate high levels of soil $\mathrm{NO}_{3}^{-}$and the concentration of this ion may rise to several percent in the plant, before phytotoxicity becomes apparent (Maynard and Barker 1971). This is exactly the case of young seedlings which even at a high concentration of nitrate $(3.58 \mathrm{mM})$ have not revealed any toxic effects and responded with a high IAA level. In contrast, severe toxic reactions occur when $\mathrm{NH}_{4}^{+}$accumulates in plants and its translocation to shoots is especially deleterious (e.g. Puritch and Barker 1967). This may explain why the very high concentration of ammonium $(3.58 \mathrm{mM}$, results not considered in the present paper) induced toxicity in pine seedlings.

However, it should be admitted that at $1.79 \mathrm{mM}$ of $\mathrm{N}$ in ammonium form the positive effect of nitrogen on the growth rate of the seedlings clearly exceeded that of nitrate at the same $\mathrm{N}$ concentration. Urea nutrition seems to play, in conditions of the present experiment, a very special role which probably depends on the mechanism of urea uptake and transformation by the pine seedlings. Intact molecule absorption or hydrolysis of urea to ammonia and carbon dioxide can be involved in the metabolism of urea-fed plants (Bollard 1959, Stew ard and Pollard 1957). Ammonia accumulation inside 
the roots as well as some intermediates of urea hydrolysis are considered to be toxic to the plant (ref. Court et al. 1962). Besides, the urea molecule has no charge. This means that the molecule very easily penetrates the free space and possibly even through the membrane of the surface of the cytoplasm. This can be an explanation why in present experiments the growth of plants and IAA level so quickly responded to the relatively low level of urea $(0.36 \mathrm{mM})$ and also why in the case of urea, the phytotoxic effect was so quickly pronounced.

Therefore manipulating with various sources and levels of nitrogen in fertilizing of coniferous plants seems to be important. However, it should be considered that coniferous seedlings differ greatly in their ability to absorb and utilize various forms of nitrogen (Evers 1964). The most favourable nitrogen sources also change often with the age of plant, $\mathrm{pH}$ of the soil, the concentration of some other nutrients and with the carbohydrate content in the plants.

But it seems that at least for the young pine seedlings, great attention should be paid to the fact that various nitrogen sources used at the same concentration can cause very different physiological effects.

\section{REFERENCES}

Andersson B., Sandberg G., 1982. Identification of endogenous N-(3-indoleacetyl) aspartic acid in Scots pine (Pinus sylvestris L.) by combined gas chromatography - mass spectrometry, using high performance liquid chromatography for quantification. J. Chromatogr. 238: 151-156.

Bollard E. G., 1959. Urease, urea and ureides in plants. Symp. Soc. Exp. Biol. XIII: 304-329.

Court M. N., Stephen R. C., Waid J. S., 1962. Nitrite toxicity arising from the use of urea as a fertilizer. Kungl. Landbr. Acad. Handl. Tidskr. 194: 1263-1265.

Evers H., 1964. Die Bedeutung der Stickstofform für Wachstum und Ernahrung der Pflanzen, insbesondere der Waldbaüme. Mitt. Ver. Forsl. Standortskunde und Forstpflanzenzucht. 14: 19-37.

Hayness R. J., 1986. Mineral nitrogen in the plant-soil system. R. J. Hayness (ed.), Academic Press.

Larsen P., 1955. Growth substances in higher plants. In: Modern methods of plant analysis. Vol. III K. Paech, M. V. Tracey (eds.), Springer-Berlin-Göttingen-Heidelberg, pp. 565-625.

Maynard D. N., Barker A. V., 1971. Critical nitrate levels for leaf lettuce, radish and spinach plants. Commun. Soil Sci. Plant Anal. 2: 461-470.

Michniewicz M., Rożej B., Stopińska J., 1976. The influence of nitrogen nutrition on the dynamic of growth and metabolism of endogenous growth regulators in Scotch pine (Pinus sylvestris L.) seedlings. Acta Soc. Bot. Pol. 45: 495-510.

Pilet P. E., 1957. Dosage photocolorimetrique de l'acide B-indolylacetique: application à l'étude des auxine-oxydases. Rev. Fen. Bot. 64: 106-122.

Puritch G. S., B a r ker A. V., 1967. Structure and function of tomato leaf chloroplasts during ammonium toxicity. Plant Physiol. 42: 1229-1238.

Rudawska M. 1987. The influence of mineral nutrition on synthesis of growth regulators in the host plant Pinus sylvestris L. and in the mycorrhizal fungus Suillus luteus (L. ex Fr.) S. F. Gray. Arboretum Kórnickie 32: 221-230.

Sandberg G., 1984. Biosynthesis and metabolism of indole-3-ethanol and indole-3-acetic acid by Pinus sylvestris L. needles. Planta 161: 398-403. 
Sandberg G., Anderson G., Dunberg A., 1981. Identification of 3-indoleacetic acid in Pinus sylvestris L. by gas chromatography - mass spectrometry, and quantitative analysis by ion-pair-reversed-phase liquid chromatography with spectrofluorimetric detection. J. Chromatogr. 205: 125-137.

Sandberg G., Erikss on A., 1987. Seasonal changes of the indole-3-acetic acid concentration in shoots and living stem bark of Scots pine trees and effects of pruning. Tree Physiol. 3: 173-183.

Sandberg G., Ernstsen A., Hamnede M., 1987. Dynamics of indole-3-acetic acid and indole-3-ethanol during development and germination of Pinus sylvestris seeds. Physiol. Plant. 71: 411-418.

Steward F. C., Pollard J. K., 1957. Nitrogen metabolism in plants. Ten years of retrospect. Ann. Rev. Plant Physiol. 8: 65-114.

Wplyw zróżnicowanego nawożenia azotowego na wzrost siewek sosny pospolitej $i$ zawartość kwasu indolilo-3-octowego $w$ iglach

\section{Streszczenie}

Jednoroczne siewki sosny przeniesiono ze szkółki leśnej do szklarni i podlewano pożywkami zawierającymi azot w różnych formach i stężeniach (mocznik 0,36 mM i 0,90 mM, winian amonowy $0,36 \mathrm{mM}$ i $1,79 \mathrm{mM}$, azotan wapniowy $0,36 \mathrm{mM}, 1,79 \mathrm{mM}$ i $3,58 \mathrm{mM}$ ). Po upływie 10 miesięcy porównywano wzrost siewek oraz poziom zawartości kwasu indolilo-3-octowego (IAA) w igłach. Zróżnicowane nawożenie azotowe wpłynęło silnie na wzrost pędów, słabiej na wzrost korzeni. Największy przyrost masy pędów nastąpił w obecności winianu amonowego o stężeniu $1,79 \mathrm{mM}$. Najmniejsze stężenie mocznika $(0,36 \mathrm{mM})$ wywołało podobny efekt jak największe stężenie azotanu (3,58 mM). Nawożenie azotowe znacznie zwiększyło ilość auksyny w igłach sosny. Największą akumulację IAA stwierdzono w siewkach traktowanych mocznikiem w małych stężeniach. 